\title{
On the Edge
}

\author{
The Role of Food-based Safety Nets in Helping \\ Vulnerable Households Manage Food Insecurity
}

\section{Lynn Brown ${ }^{1}$ and Ugo Gentilini ${ }^{2}$}

October 2006

\begin{abstract}
Safety nets have often been controversial instruments, condemned in some circles as short-term palliatives or even a waste of money. Much recent evidence shows that safety nets not only support poverty reduction but also economic growth. The existence of safety nets encourages adoption of higher income livelihood strategies that are associated with higher, but prudent, risk. Safety nets should be one component of a broader social protection strategy, which uses a plethora of instruments to address a wide array of risks and associated vulnerability. For the poorest of the poor one of their key concerns is access to sufficient food for a healthy and active life. Food-based safety nets are therefore an important instrument for some of the poor and food insecure who are vulnerable to critical levels of food deficit. Integration of safety nets within broader social protection strategies enables a more cohesive relief and development approach, as opposed to a relief to development continuum or more linear approach. This more approximates reality where relief and development activities generally coexist.
\end{abstract}

Keywords: social protection, food based safety nets, vulnerability, food insecurity JEL classification: D6, I3, O1

\section{Copyright @ C UNU-WIDER 2006}

1 World Bank, Washington, DC; email: lbrown3@worldbank.org; 2 World Food Programme, Rome; email: Ugo.Gentilini@wfp.org

This paper was prepared for the UNU-WIDER project on Hunger and Food Security: New Challenges and New Opportunities, directed by Basudeb Guha-Khasnobis. The project was carried out in collaboration with the Indian Council of Social Science Research (ICSSR) and the UN Food and Agriculture Organization (FAO).

UNU-WIDER gratefully acknowledges the financial contributions to its research programme by the governments of Denmark (Royal Ministry of Foreign Affairs), Finland (Ministry for Foreign Affairs), Norway (Royal Ministry of Foreign Affairs), Sweden (Swedish International Development Cooperation Agency_Sida) and the United Kingdom (Department for International Development). 


\section{Acknowledgements}

An earlier version of this paper was presented at the First Workshop of ICSSR-WIDER Joint Project on Food Security, 4-6 March 2005, Jaipur, India. The authors thank all participants and the conference organizers Ben Davis and Basudeb Guha-Khasnobis for their useful comments. Lynn Brown is rural development specialist at the World Bank (Washington, DC) and Ugo Bentilini a development policy economist at the World Food Programme (Rome, Italy). The views represent those of the authors and should not be attributed to WFP or the World Bank

The World Institute for Development Economics Research (WIDER) was established by the United Nations University (UNU) as its first research and training centre and started work in Helsinki, Finland in 1985. The Institute undertakes applied research and policy analysis on structural changes affecting the developing and transitional economies, provides a forum for the advocacy of policies leading to robust, equitable and environmentally sustainable growth, and promotes capacity strengthening and training in the field of economic and social policy making. Work is carried out by staff researchers and visiting scholars in Helsinki and through networks of collaborating scholars and institutions around the world.

www.wider.unu.edu

publications@wider.unu.edu

UNU World Institute for Development Economics Research (UNU-WIDER)

Katajanokanlaituri 6 B, 00160 Helsinki, Finland

Camera-ready typescript prepared by Liisa Roponen at UNU-WIDER

The views expressed in this publication are those of the author(s). Publication does not imply endorsement by the Institute or the United Nations University, nor by the programme/project sponsors, of any of the views expressed. 


\section{Introduction}

The conventional wisdom in mainstream development policy circles is that income transfers to the poor, and safety net policies more generally, are at best a short-term palliative and at worst a waste of money. They are not seen as a core element of an effective long-term poverty reduction strategy.

This is the opening paragraph of Ravallion (2003) and seems to condemn all safety nets, whether transferred in food or cash, as putting brakes on the economic development process. But as Ravallion demonstrates, a wide body of evidence now exists that indicates there are many circumstances in which safety nets, as part of carefully planned social protection policies, can be a springboard for the poor to escape poverty.

Ravallion identifies a number of reasons why the tradeoff between economic growth and lower inequality fostered by public transfers may be a false one. The most fundamental of which is the existence of the human basal metabolic rate-without an adequate food energy intake to support the functioning of the human body at rest there can be no productive activity at all. Thus, transfers that ensure beneficiaries can meet at least some measure above minimum energy requirements are essential if people are to contribute to economic growth.

While the debate continues within economic development circles as to whether safety nets are a brake on the development process, costs for which there is no economic return, in other development fora there is a growing focus on rights-based approaches. Adopting a rights-based approach to social protection makes the economic arguments largely mute. Under the International Covenant on Economic, Social and Cultural Rights (ICESCR) every person has a right to an adequate standard of living, including food, clothing, housing, medical care, social services and social security. Thus all countries that have ratified the ICESCR also agreed to the progressive realization of the enshrined rights, including those related to an adequate standard of living. Many subsequent conferences and summits have reaffirmed the right to food. Within the last decade these include the World Summit for Social Development and the Beijing Conference on Women both in 1995, and the Rome Declaration on World Food Security and the World Food Summit Plan of Action in 1996, and the follow up five years later in 2002. The World Food Summit: 5 Years agreed to an inter-governmental process to develop voluntary guidelines on the implementation of the right to food. These guidelines were formulated and adopted in 2004.

In this paper we show that safety nets do support economic growth, and poverty and food insecurity reduction. Our focus is on a subset of overall safety net instruments - the use of food-based safety nets, often explicitly geared to the achievement of food security objectives, rather than all safety net instruments.

Section 2 explores the evolution of food security. In section 3 the interplay of vulnerability, risk management and the dynamics of food security is examined. Section 4 introduces the role of safety nets to address food insecurity. The section discusses the debate on whether to use food or cash as the instrument of transfer, briefly discusses targeting and outlines the most commonly used food-linked transfer programmes. 


\section{Exploring food insecurity}

Analytically and operationally the concept of food insecurity has undergone significant change over the past three decades (see Figure 1 and Haddad and Frankenberger 2003; Maxwell and Slater 2003).

Food insecurity emerged in the international development agenda in the 1970s following the food price spikes of that period and the concerns about food availability (Maxwell 2001, 1998, 1996). Thus the focus was predominantly on global and national food production and stocks. In the 1980s the focus began to shift, sparked in part by Amartya Sen's pioneering work on famines (Sen 1981). The 1980s were also marked by the early years of structural adjustment policies, and what many believed to be an overemphasis on a gross domestic product definition of poverty, which failed to fully capture the multiple manifestations of poverty including hunger. This led to a greater focus on households' economic constraints in accessing the food that was available. The 1990s witnessed greater attention on the utilization dimension of food insecurity, encompassing dietary diversity, and adequate complementary resources, such as health care, safe water and sanitation to ensure that adequate food consumption translated into good nutritional outcomes, and nutritional security. The 1990s also saw a growing focus on the role of women in food security, supported by economic analysis on intrahousehold distribution of resources (Quisumbing et al. 1995; Haddad, Alderman and Hoddinott 1997).

The year 1996 also saw the World Food Summit where the agreed definition of food security captured the evolving elements of the last 25 years: 'Food security exists when all people, at all times, have physical and economic access to sufficient, safe and nutritious food to meet their dietary needs and food preferences for an active and healthy life' (FAO 1996).

The late 1990s and the first four years of this millennium have seen a growing focus on an often neglected part of this definition: at all times. Food security is often seen as built on three pillars, availability (food is available through local, national or international food production), access (economic: individual, household, national income to purchase sufficient food) and utilization (safe, nutritious and diverse to meet needs). As noted by

Figure 1

The evolution of thinking about food insecurity

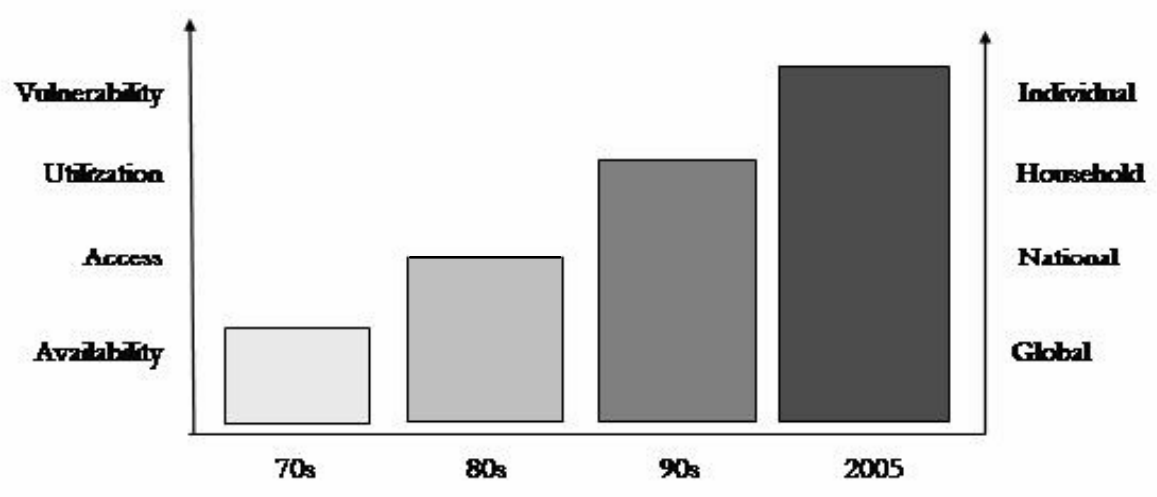

Source: Computed by the authors. 
Haddad and Frankenberger (2003) 'too often strategies to reduce food insecurity have been operationalized considering only the first three components of the food security definition. [...]. The perspective that both emergency and development actors are missing is vulnerability'. This reflects the concept in the food security definition that a household that does not always know it will be able to put sufficient food on the table to adequately feed all its members is not food secure even if they have been able to do it for the last week, or month. Figure 1 indicates the general direction in which the thinking on food security has evolved in the last three decades.

\section{Vulnerability, risk management and food insecurity dynamics}

The concept of vulnerability has stimulated new analytical refinements which have greatly contributed to a better understanding of the processes that lead to food insecurity. Vulnerability arises from a complex web of economic, political and social conditions (see Figure 2), a process of cumulative conditions which vary over time and space depending largely on the changing processes by which individuals, households and communities fulfil their immediate subsistence needs and invest in medium- and long-term reproduction of their social system (WFP 2002; Alwang, Siegel and Jorgensen 2001; Siegel and Alwang 1999).

While complexity underlies the definition 'living on the edge', it provides a graphic image of the livelihood circumstances that vulnerability conveys. Living on the edge evokes the image of a small push sending a person or people over the edge, and it is just

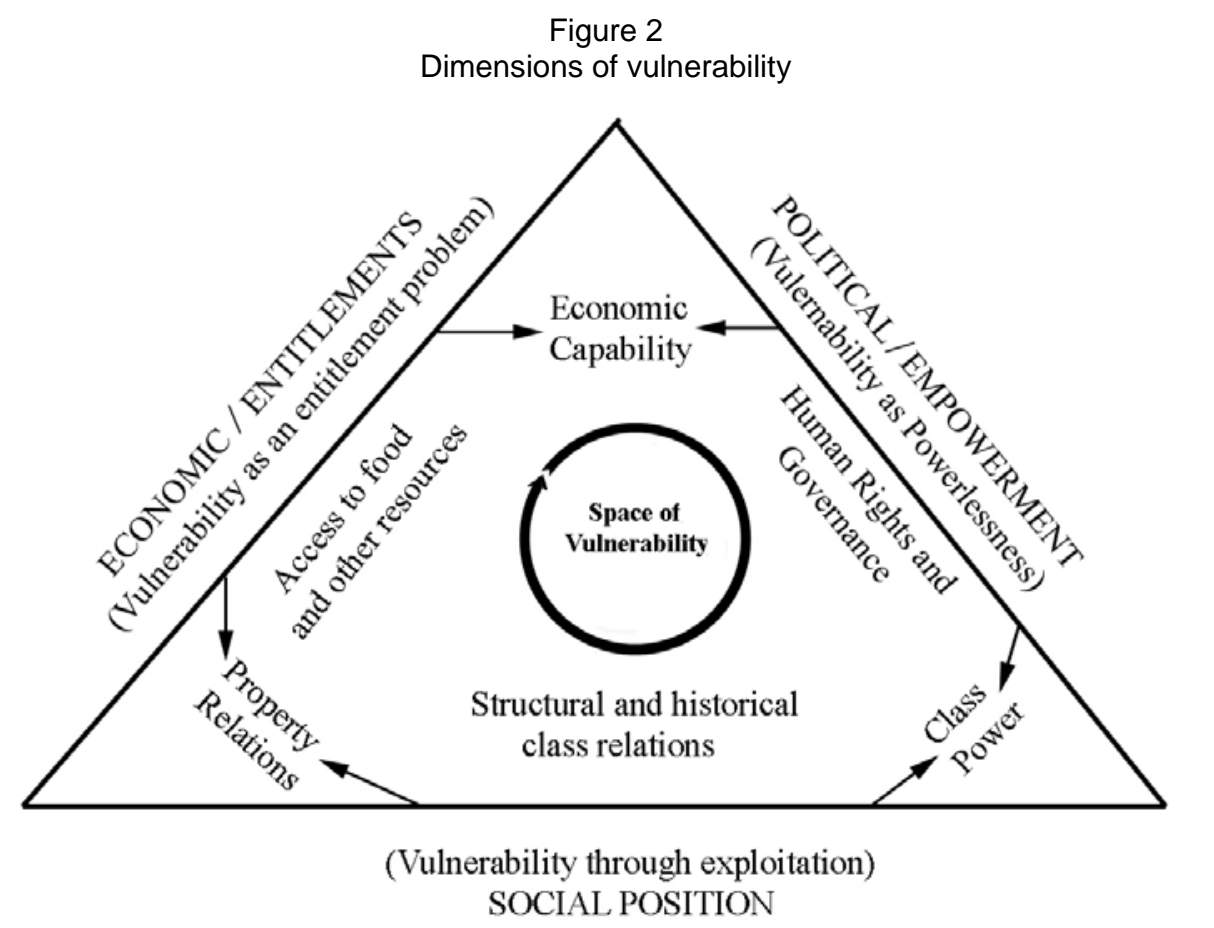

(Adapted from Watts and Bohle, 1993) 
this knife-edge between ability to survive and thrive, and sudden loss of ability to do so, that vulnerability seeks to describe (Ellis 2003).

However, quantifying vulnerability is like 'trying to measure something that is not there, making the search for a visible reference point a difficult task' (Webb and Harinarayan 1999: 298). Vulnerability can be addressed only by adopting a relative approach without referring to a defined benchmark or 'gold standard', such as with nutritional outcomes (Hoddinott and Quisumbing 2003; Ligon and Schechter 2002; Maxwell et al. 1999). Single measures of deprivation, such as the head-count indicator of poverty, capture basic information on the present condition but vulnerability seeks to capture the underlying causal processes that led to the actual status, and which will probably influence future conditions (Lautze et al. 2003). According to Frankenberger (2003: 21), 'poverty and food insecurity are essentially static concepts whereas vulnerability is dynamic and describes how people move in and out of poverty and food insecurity'.

It is now widely recognized that vulnerability can be lessened through effective risk management strategies aimed at (i) reducing the exposure to risks, (ii) increasing the ability to manage risks, or (iii) both1 (Haddad and Frankenberger 2003). While (i) enshrines the likelihood that individuals or households will be affected by a shock (i.e., the realized risk), (ii) captures individual's or household's ability to manage such threats, either before or after they occurred (Heitzmann, Canagarajah and Siegel 2002).

The inability of the poor to manage risks may constrain them to poverty and food insecurity despite opportunities for escape. There are two possible explanations for this: dynamic poverty traps and livelihood choices that minimize risk at the expense of potentially higher incomes.

One condition for a dynamic poverty trap lies in the necessity for human beings to consume sufficient food to provide energy in excess of the basal metabolic rate if they are to engage in productive activity. The productive activity must also generate sufficient income to compensate for the energy expended if the individual is not to enter a downward spiral. In essence, a dynamic trap means that a shock can drive household to such a level that it is unable to recover its previous income path. Studies by Jalan and Ravallion (2001) and Lokshin and Ravallion (2001a), the former using date from China and the latter from Hungary and Russia, show little evidence of dynamic poverty traps. In all cases households did bounce back from transient shocks, but those who were already on low-income paths took longer to recover, thus potentially giving the impression of dynamic poverty traps.

Perhaps the more common issue is that poor people make choices regarding their livelihoods which despite improved livelihood possibilities, consign them to poverty because of their inability to access risk management instruments and their inability to 'self insure' the risk through savings and prior asset accumulation. This is evidenced in many ways, particularly in rural areas, home to the majority of the world's poor and food insecure. New agricultural technologies maybe ignored if more risky than the traditional (Morduch 1995). Households may grow more food crops and less higher

1 Public risk management can occur at various levels (at individual, household, community, national and regional level). 
value commodity crops, despite lower overall aggregate income. This enables them to insure, in a consumption sense, against food price risk in the market place (de Janvry, Fafchamps and Sadoulet 1991). Kurosaki and Fafchamps (2002) show that in Pakistan, crop choices are determined more by concerns about risk than technological considerations of joint production. Households rearing livestock for milk production tend to be selfsufficient in fodder production despite an active fodder market. Milk production is sensitive to fodder prices, so households choose to be selfsufficient in fodder to reduce the risk of milk production losses due to fodder timeliness and price variability inherent in market reliance. They conclude that an elimination of fodder price risk would increase welfare by 5 per cent, an elimination of all risk would raise basmati rice cultivation by 30 per cent and hence income by 2 per cent, and welfare by 9.4 per cent. Jalan and Ravallion (2001) show that the poor in China hold wealth in unproductive, but readily realizable as income, mediums rather than in higher-return mediums. However, this behaviour is not adopted by the poorest quintile, presumably because they cannot afford to do so, nor by the richest quintile because they have alternative asset holdings available. Estimates indicate that poorer households have higher levels of risk aversion that wealthier. In Pakistan relative risk aversion varied from 1.8 to 20, with the largest values associated with the poorest households (Kurosaki and Fafchamps 2002). The average value in this study was 3.6, higher than values that Fafchamps and Pender (1997) find in India (1.8 to 3.1) but consistent with early estimates by Binswanger (1980).

Risks and shocks are not the same phenomena because not all risks materialize and become shocks. While some risks cannot be eliminated, for example, most of the natural ones, most can be anticipated enabling an element of advance planning. Other risks can be de facto eradicated, such as polio and even malaria, a contributor to undernutrition and premature death in many parts of the developing world. When risk cannot be eliminated, the burden of risk management relies on the active provision of effective instruments to find a way to live with these phenomena (ISDR 2002: 5). In other words, 'enhancing resiliency does not mean reducing the number of shocks. [...] Reducing vulnerability rests on helping communities better manage the many risks that they face on a daily basis' (Webb and Rogers 2003: 8).

Three broad classes of risk management are usually identified, namely 'prevention', 'mitigation' and 'coping' strategies (Heitzmann, Canagarajah and Siegel 2002; Holzmann and Jorgensen 2000; Alderman and Paxson 1992). While prevention and mitigation strategies are both ex ante (i.e., undertaken before the shock materializes), the prevention ones reduce the probability of the shock from occurring, whereas mitigation strategies are aimed at reducing the potential impact of the shock when it does occur, for example through livelihood portfolio diversification or insurance mechanisms. While ex ante risk management actions may appear costly, as demonstrated by Walker and Ryan (1990) who find that households in semi-arid areas of India may sacrifice up to 25 per cent of their average incomes to reduce exposure to shocks, households are clearly willing to pay for more certain income streams. This demonstrates the value of risk management instruments to households. Effective public action that supports provision of such instruments, either public or private, would enable many of the poor to find their way out of poverty by adopting alternative livelihood paths that offer higher potential income profiles. 


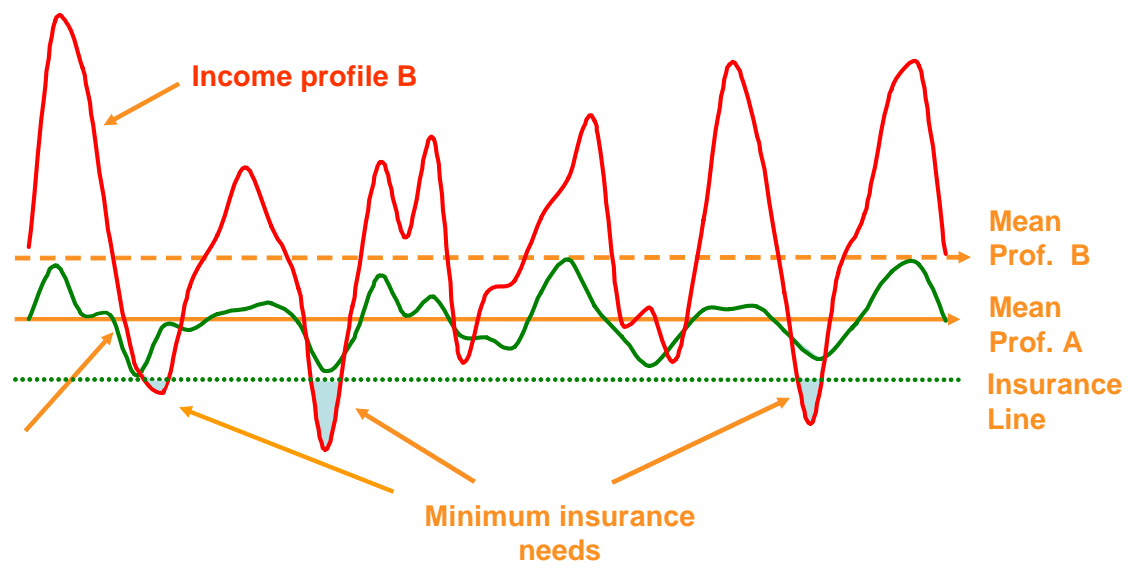

Source: Computed by the authors.

Figure 3 shows two expected income profiles: A with a low mean but also a low associated variance/risk, and B with a higher expected mean but also higher associated risk/variance. A poor household will not adopt a livelihood strategy commensurate with profile $B$ if they are unable to withstand the very low troughs in income that are possible. A simplified example may be a household living in an area which is prone to droughts, with insecure land tenure. Profile A may be represented by growing cassava, a food crop that is drought tolerant, with a fairly short maturation period and is locally marketed, or profile B by growing coffee, a long gestation cash crop. The income from coffee is far higher but carries the risk of not being drought tolerant, or potentially losing the land before the coffee plants reach maturity, or the harvest occurring at a trough in the international coffee price. Any one of these events or some combination could result in the very low troughs apparent in income profile B. A variety of risk management strategies and instruments, both public and private, could address these problems and enable a household to adopt profile B. Two strategies are apparent; reduce the variance of the income profiles by reducing the downside risk, hence raising expected mean income; or protect individuals and households should the risk exposure be realized. Investment in irrigation reduces the risk exposure to drought. A land registration programme that is sensitive to traditional tenure patterns, also promoting access by women, as opposed to single-right privatization reduces the risk exposure of loss of land. Investment in physical infrastructure, such as roads and health clinics, can reduce the volatility of prices caused by local supply fluctuations and reduce the incidence of health shocks. Insurance instruments, such as weather-based and/or commodity risk management instruments, provide protection against drought and/or the coffee being sold at a time of lows in the global price, thus reducing the size of the troughs in income profile B.

Figure 3 is in essence a map of income profiles with higher and higher means. The goal of social protection should be to ensure that there is an array of risk management instruments available to households to enable these to move progressively from one income profile to a higher one. At some point their expected mean income would be above the poverty line. At the very lowest income profiles, it is likely that the instruments that remove the lowest troughs are publicly provided and fall in the social assistance genre. However, that does not make them unproductive, their existence enables households to adopt livelihoods consistent with higher-income streams in the 
knowledge that there is a safety net. As the income level increases the needed risk management instruments are likely to be a mix of public and private instruments, including insurance schemes for commodity risk or weather for agriculture households, as well as other forms of insurance such as health insurance or unemployment insurance. Weather-based insurance can be accessible and paid for even by poor farmers. It not only protects them against the impact of a drought, flood, or other weather-based events for which the insurance is underwritten but increases their access to credit. Lenders recognize the income stream is more secure, thus farmers can increase productivity through the purchase of inputs such as fertilizer and pesticides. The current issue is the availability of risk management instruments. A range of social protection instruments needs to be available and known to households to enable them to take on prudent risks, but the portfolio used by households will depend on where they lie in the income spectrum.

The unavailability of risk management instruments condemns households to coping strategies, undertaken to relieve the impact of shocks once they occur, which may be more costly than ex ante risk management. These ex post strategies usually involve the depletion, erosion and dis-saving of household financial, physical, human and natural capital. Poor households may be unable to fully cope or recover from a shock, becoming even more vulnerable to the next shock. Their asset holdings may be minimal and thus they are rendered destitute by the smallest income loss, running the risk of irreversible damages to their wealth base (Alderman, Hoddinott and Kinsey 2003). According to Maxwell and Frankenberger (1993: 29), 'coping may be a misleading positive word, implying that food insecure households survive periods of high risk unscathed: in fact, households may survive only at a cost of significant impoverishment'.

Vulnerability is a key factor in distinguishing between chronic and transitory food insecurity. Transitory food insecurity is defined as a temporary inability to meet basic food needs or smooth food consumption levels due to periodical and cyclical fluctuations in incomes or unexpected temporary shocks. Households that persistently face deprivations over a significant timeframe (conventionally five years) are considered chronically food insecure. Chronic poverty and food insecurity are strongly associated with structural disadvantages, which are difficult to quickly reverse, typified by lack of assets, high dependency ratios, residence in remote locations, working in low-return occupational categories and chronic sickness and/or social barriers (CPRC 2004; Bird et al. 2002; McKay and Lawson 2002). Not only do some of the chronically food insecure remain so for most of their lifetime, the condition is often transmitted to the next generation (Moore 2001).

\section{Looking at the most food insecure: the role of social safety nets}

In this section we provide an overview of safety nets in the context of social protection strategies, the mechanisms that protect those at risk on the lowest troughs in income profile in Figure 3. We examine the modalities for identifying intended beneficiaries, and the different instruments in the food-based safety nets portfolio.

Policymakers, academics and practitioners often equate welfare, social security, safety nets, social assistance or social insurance mechanisms to social protection. Many of these terms have overlapping meanings, and all form components of social protection 
strategies, but individually they do not equate to social protection. Social protection is the overarching policy framework that ensures cohesion among the various components, and the World Bank's social protection sector strategy or the studies undertaken at IDS and ILO have clearly shown the need to move beyond mere transfers towards comprehensive forward-looking policies² (GTZ 2004; Devereux 2003; Van Ginneken 2003; World Bank 2001).

The new discourse around social protection recognises that in the absence of effective collective arrangements to manage risks, individuals and households are forced to engage in micro-level, informal risk management strategies which frequently impose very high costs of their own. Interventions by governments should act on the risk management systems that already exist, with the objective of supporting functional behaviour and institutions and weakening dysfunctional behaviour and opportunities 3 (Shepherd 2004; Conway and Norton 2002). Public risk management policy should be 'to combine the best of private strategies with various public transfer programmes' (Webb 2003: 16). Effective policymaking requires a nuanced understanding of poor people's temporal decision framework and their livelihood strategies. This supports programme design that maximizes the effectiveness of private arrangements and supplements with public provision where optimal. Sophisticated diagnostic products, such as WFP's Vulnerability Analysis and Mapping or the World Bank's Risk and Vulnerability Analysis, have been designed to support such policymaking by illuminating the 'who', 'what', 'where' and 'why' of food insecurity.

Safety nets are a key pillar of social protection strategies, and the literature documenting their objectives and functions is very rich (Coady, Grosh and Hoddinott 2004; WFP 2004; Morley and Coady 2003; Subbarao 2003; Alderman 2002; Barrett 2002; Devereux 2002a; Rogers and Coates 2002; Tabor 2002; Castaneda 2000; Subbarao et al. 1997; Grosh 1994). Safety nets comprise both social assistance and social insurance functions (Haddad and Zeller 1996). The social assistance function is designed to bring households up to some minimum standard of living. This is the element of social protection most geared towards a government fulfilling its obligations under human rights considerations. Social insurance on the other hand provides a minimum floor to household income levels, for example to enable households to follow income path B in Figure 3. It ensures that in the event that a shock occurs a household is assured of a certain level of wellbeing.

Safety nets need to be in place before a shock occurs, particularly from a social insurance perspective. The delivery instrument can be cash, in kind, with the most

2 However, this does not mean that in certain circumstances 'pure' transfers without any reciprocity are inappropriate (e.g., the welfare component of Table 1). Moving from narrower social assistance programmes to broader social protection strategies does not deny the importance of social assistance per se, but does emphasize the need for expanding the policy perspective (and consequent operational linkages).

3 It is often argued that public action should not 'crowd out' informal risk management mechanisms, which in certain and well-defined circumstances may seem a contradiction when the objective is to stimulate a behavioural change (e.g., lessening risk aversion). Following Conway and Norton (2002: 537), ' $\ldots$ the rationale for state action to reduce households' exposure to risk and to help ameliorate the effects of shocks which do occur is at least partly to provide, through more efficient and equitable collective arrangements, a less onerous means of protection against vulnerability. [...] Furthermore, state action may also include "crowding in" of other transfers'. 
common in-kind instrument being food, or increasingly a hybrid with the transfer given in cash or near cash but conditional on certain behaviour or activities.

\subsection{Why food-based safety nets?}

Any food-based transfer which is infra-marginal, i.e., less than the household already consumes, can in essence be converted to cash if the household reduces its own purchase of the transferred item by an equal amount. This raises the question of why use food as a transfer instrument. Food distribution is often more challenging logistically than cash - transport, spoilage, packaging — and thus more costly to deliver. However, there are several reasons why food or food linked transfers are preferred: (i) impact on food related outcomes, such as child calorie consumption and health care utilization, may be greater; (ii) in food deficit areas with disrupted or unresponsive markets where cash transfers would result in increasing food prices; (iii) security costs may be lower with regard to food distribution than cash; (iv) cash and food are often not substitutable in terms of donor resource availability; and (v) political support for food linked transfers may be higher. The first is the key reason why a food-based transfers may be optimal when the goal is a food and nutrition security related outcome, as opposed to a poverty reduction outcome. A hungry population cannot learn, is less productive, more frequently ill, and more likely to die prematurely. The second reason is optimal if a cash transfer would increase food prices sufficiently to reduce the value of the transfer significantly, given the poor spend the majority of their income on food, and to push other non beneficiary households into or deeper into poverty.

A direct income transfer to a poor household will always reduce the shortfall between households' pre- and post-transfer income and hence degree of poverty. However, an income transfer will not always have the same level of impact on the nutrition or food security outcomes of a household as a cash equivalent transfer. Therefore, if a food security or nutrition related goal is the key objective, careful consideration needs to be given to the targeting mechanism and available instruments in order to make the choice between cash and food. In some cases, food maybe the preferred transfer mechanism. However, the instrument of transfer, whether cash or food, should be appropriate to both the programme objectives and the target group. Too often criticism is levelled at a programme because it did not reach a particular target group. Understanding the target group is a key criteria in picking both the transfer medium and instrument. For example, a public works programme is not appropriate for a target group of households that lacks available labour, either due to its demographic profile or because its working age population has high morbidity due to AIDS related illness.

i) In theory, food or cash-based transfers should have the same impact on household food consumption at the margin. But the reality may be somewhat different, depending on the gender of the transfer recipient and the knowledge base of the beneficiaries. The economist's notion that a household has a single preference/utility function, whether common to all members or imposed by a household dictator, has been shown to be erroneous by numerous studies. This means the identity of a transfer recipient within a household matters to the desired outcome. Evidence indicates that the marginal dollar of household income in the hands of a woman is far more likely to be spent on food consumption, and on children's wellbeing such as health care and education. As the household's food utilization is normally under the control of a woman, 
transfers in the form of food may be more likely to remain under women's control and can be combined with other desired behavioural change. In Guatemala, the increase in household food expenditures would be almost double if the average yearly profits from nontraditional agricultural exports were in the hands of women (Katz 1992). In Brazil certain income sources in the hands of a woman, rather than a man, increase the likelihood of child survival in urban areas almost 20 fold (Thomas 1994). This means that if a food security or child welfare outcome is a key objective, then the choice of instrument used to transfer cash has to be carefully chosen to ensure it goes to women. When cash transfers are used they often use conditionality as one mechanism to ensure the transfer goes to women. The conditionality is usually based on a household behaviour which falls in the female domain, such as taking children for health checks, immunization and growth monitoring.

ii) A food transfer instrument is necessary in areas where food markets are either not functional or have limited functionality. This may be due to security concerns, such as civil conflict and unrest, or because lack of effective purchasing power combined with remote locations and lack of infrastructure have resulted in market failure. In these situations cash-based transfers would merely increase local food prices, resulting in limited, if any, increase in food consumption (Webb and Von Braun 1994).

iii) While direct food distribution may be logistically more complicated (bulky commodity, transportation, storage, etc.) and more expensive, there are often more security concerns using cash in economies where corruption and crime are serious issues. This is particularly true in areas where food aid delivery is most expensive, such as remote rural areas where, given the lack of rural finance institutions, cash may be the only suitable monetary alternative. While food is not immune to theft, its magnitude makes it more difficult and involves an extra transaction cost to realise a cash value. It was noted in a public works programme in Honduras that cash wages were delayed as only two workers were authorized to distribute cash wages to reduce the likelihood of theft or corruption. The food for work programme, however, delivered payments on time (Rogers and Coates 2002).

iv) If food aid and cash were substitutable, food aid would follow a countercyclical cycle compared to food supplies being given according to need. When global grain production declines and stocks are low, the international price increases. Poor food-deficit countries are less able to finance their food needs through food imports, increasing the demand for food aid. But high food prices tend to be linked to lower availability of food aid not higher (Figure 4). This leads some to draw a conclusion that food aid transfers are linked to the agricultural policies of the OECD countries, and in particular to their agricultural subsidy policies. Food aid is argued to be the channel by which many OECD countries utilize their surplus production and maintain support to domestic agriculture prices. 


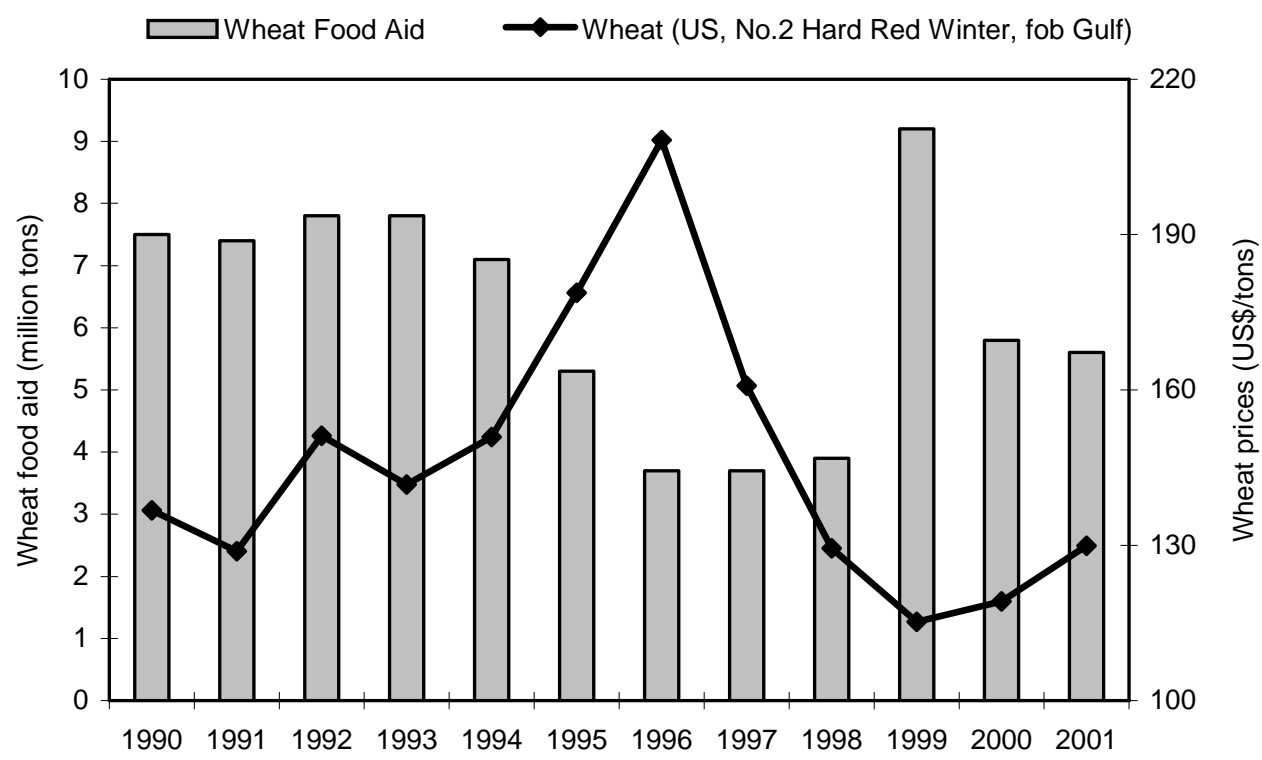

Source: Computed by the authors, based on data from FAO and WFP.

Thus food aid and cash are unlikely to be perfectly substitutable from a donor perspective with an equal cash donation replacing a food aid donation. Food aid is used in three main forms by donor governments: (i) bilateral budget support to a country government, usually monetized in the marketplace of the recipient country; (ii) directed through the United Nations World Food Programme where it is used as targeted project food assistance; (iii) directed to nongovernmental organizations where it may be monetized or used as targeted project food assistance. Of late, many countries are untying their food aid to WFP, replacing in-kind contributions with cash. This can increase the developmental impact, as food commodities can be sourced directly in the recipient country or in a third neighbouring country and increase efficiency (OECD DAC 2005).

Political support is critical to the sustainability of all safety net programmes, particularly as the prime beneficiaries are not normally those with strong political voice. Programmes - and the associated instruments-are more likely to be supported if there are clear eligibility mechanisms and if they are available to all when the eligibility criteria are met. For many, transfers in food are more politically acceptable as they appear to constrain people to good behaviour and to prevent beneficiaries from using an 'income' transfer for less desirable purchases such as alcohol and cigarettes. This was demonstrated in the USA when a cash transfer programme was rejected by the US legislature as too generous while they subsequently agreed to an increase in food stamp benefits beyond the value of the proposed cash transfer plan (Rogers and Coates 2002). In Latin America increasing political support is demonstrated for conditional cash transfer programmes, where the conditionality is linked to good behaviours such as child growth monitoring, school attendance, etc.

While the 'food versus cash' debate is often intense, empirical evidence on the right balance between the two is lacking. Non-food resources play a critical role in 
complementing food-assisted programmes, ensuring better targeting and delivery to the most remote areas (Webb 2003). Oxfam reports that in the early stage of a flood response in Bangladesh, food was more appropriate than cash, given the 50 per cent rise in the price of rice due to many closed markets because of food supply access problems caused by the flooding (Khogali and Takhar 2001). When repairs were made and markets became functional, transitioning to cash would have been more appropriate.

Table 1 summarizes the core dimensions for selection between food and cash.

Table 1

Food versus cash

\begin{tabular}{|c|c|c|}
\hline Food Transfers & Cash Transfers & Cross-Cutting Issues \\
\hline 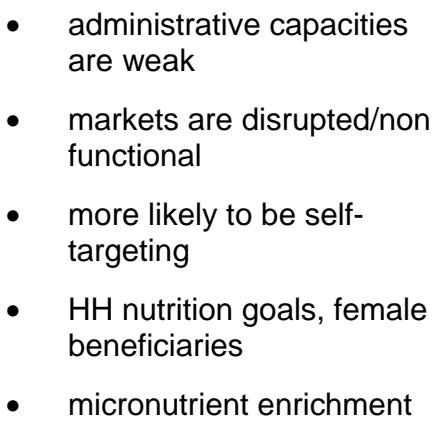 & $\begin{array}{l}\text { - } \quad \text { where capacities to manage } \\
\text { them are in place } \\
\text { - } \quad \text { well functioning markets } \\
\text { - less costly to manage } \\
\text { - fungible - no food } \\
\text { security/nutrition goals } \\
\text { easier to combine with } \\
\text { near-cash transfers }\end{array}$ & $\begin{array}{ll}\text { - } & \text { administrative costs } \\
\text { - } & \text { political sensitivity } \\
\text { - } & \text { targeting mechanisms and } \\
\text { errors } \\
\text { - } \\
\text { disincentives and } \\
\text { distortions } \\
\text { - } \quad \text { crowding-out effects }\end{array}$ \\
\hline
\end{tabular}

Source: Barrett and Maxwell (2005); Abdulai, Barrett and Hazell (2004); Coady, Grosh and Hoddinott (2004); Subbarao (2003); Barrett (2002); Del Ninno and Dorosh (2002); Devereux (2002b); Rogers and Coates (2002); Tabor (2002); Castaneda (2000); von Braun, Teklu and Webb (1999); Haddad, Alderman and Hoddinott (1997).

\subsection{Targeting mechanisms}

Safety net programmes are intended to protect the poorest citizens in society or those who, as a result of a shock, find themselves temporarily below a given welfare level. This implies that the programmes need to identify the right beneficiaries. For example if 10 per cent of a population of ten thousand are below the poverty line, and the average shortfall is US\$10 then the cost to eliminate poverty without any effort made to identify the poor is US\$100,000. However, if transfers are delivered only to the poor-perfect targeting - the cost of eliminating poverty would be US\$10,000 or just 10 per cent of the cost of the untargeted programme. From a budgetary perspective, targeting involves tradeoffs between the administrative costs of obtaining information to support perfect targeting and delivery only to the target population, and the potential leakage of benefits to nontarget beneficiaries when less information is available. Generally the poorer the country, the less well developed are the information systems to support targeting.

Targeting mechanisms may be individual/household, categorical, and self-targeting with associated costs declining from individual/household to self-targeting. In most cases, more than one form of targeting method is used. For example, the target group may be school children but only those attending school in the poorest district, both categorical targeting mechanisms, or public works programmes may have low wages and only operate in certain areas, self-targeting with categorical targeting. 
Targeting mechanisms are also key criteria in ensuring political support. Instruments that are targeted to very narrow groups are less likely to gain political support. These can include some categorical targeting mechanisms, which may correspond with geographic areas with little political power by virtue of race or ethnic group.

\subsection{Food-based safety net instruments}

There is a wide array of food-based safety net instruments ranging from direct programmes where the transfer medium is food, restricting beneficiary choice completely, to indirect programmes where a cash transfer is linked to food purchase, where the choice of foods purchased can be restricted or unrestricted.

Direct food programmes include supplemental feeding, school feeding, emergency feeding, generalized food distribution, and food for work. Indirect food-based programmes include food subsidies, and food stamps or vouchers or coupons.

\section{Supplemental feeding}

Supplemental feeding is generally targeted at vulnerable groups, usually pregnant and lactating women, and young children. Whether it is preventative or palliative is a critical element in terms of whether it is an insurance or assistance function in a safety net. Supplemental feeding for pregnant women and children is often only available to pregnant women and children who are failing to thrive. In the case of pregnant women this may be below recommended body mass index thresholds or failing to gain sufficient weight, and in children low anthropometric indicators. By this stage some irreversible damage has already been done. It also provides a perverse incentive effect to households who may choose to 'behave' badly in order to qualify for food assistance. In the poorest communities, it therefore makes sense to have an inclusive rather than a targeted programme. However, for outcomes to be sustainable, it is critical that nutritional education components are also central to the intervention.

\section{Food for education}

Food for education can take place on site through the provision of meals or through take-home rations. These programmes have been controversial in terms of their impact on nutritional outcomes. Many argue that the greatest vulnerability of a child to undernutrition is pre-school. This highlights the need to evaluate a programme by its objectives and clearly school feeding is not meant to tackle undernutrition in preschoolers. School feeding programmes have many benefits, many of which extend beyond a nutritional dimension. When done through onsite feeding, these include improving the micronutrient content of children's diets, reducing immediate hunger and improving children's learning ability. When take-home rations are used, the food is likely to be shared among household members, and thus some of the nutritional impacts above may be lost for the schoolchild. This can also happen with onsite feeding as household food may be re-allocated away from the child fed in school and towards other members perceived to be more needy. Independent of the method of implementation, school feeding provides incentive effects to encourage children to enrol and stay in school. This may be particularly effective in attracting girls to school and retaining them in higher grades. The impact of increasing girls' education should not be underanticipated, given its delaying impact on age at marriage, age at first birth, number of 
children born, and future child nutrition outcomes as well as its contribution to fulfilling the right to education.

\section{Emergency feeding and generalized food distribution}

Emergency is a social assistance function, most often used in times of crisis, precipitated by war and civil unrest or by natural disaster, to protect lives. This may take the form of therapeutic feeding for severely malnourished children, and rations or feeding for a general population currently unable to access food. The goal, particularly in natural disasters such as floods and drought, should always be to feed families within the community to prevent distress asset sales and migration. However, in times of conflict this often takes place in refugee camps or camps for internally displaced persons.

\section{Food for work}

Food for work is best used as a livelihood protection mechanism, and is best implemented with an employment guarantee. This supports an insurance function to enable households to undertake more risk in their normal livelihood strategy than they may do in the absence of the programmes, knowing that should alternative livelihood means fail, food for work is available. The advance planning also enables appropriate attention to be paid to the type of works undertaken. This ensures that appropriate community assets are constructed or renovated/rehabilitated with appropriate plans for onward maintenance rather than ad hoc programmes that can be characterized by a 'dig a hole, fill a hole' mentality. These programmes prompt intense debate in terms of the instrument of transfer, food or cash. Food is the best mechanism if there is a market failure in the area of implementation, which constrains the availability of food. Food for work may also implicitly attract more women and thus have greater food security impacts on the household, particularly child food consumption. This may have been true in Zambia and Lesotho when 50 per cent of wages were paid through food stamps, as opposed to cash, and the programmes attracted more women than men (Subbarao et al. 1997). Women participating in a food for work programme in Rajasthan (India) also reported that they preferred the food for work programme rather than a cash based one as they were able to participate. They felt that had payment been in cash their husbands would have participated and they would have been less likely to receive the money. Unfortunately these gender aspects of targeting through payment medium have been little researched. However, if women are a primary target group, it is important that the food payment is sufficient to allow for adequate household food consumption. It has been suggested that women can sacrifice their own nutritional status to protect their children's and this is a particular risk in food for work programmes where energy expenditure can be greater than energy replacement (Higgins and Alderman 1997).

Public works programmes generally use self-targeting through the wage rate. Self-targeting can be effective in social protection programmes when there are distinct behavioural differences between poorer and wealthier households. The lower the wage rate in a public works programmes, the more the programme is self-targeted to the poorer members of society. Wealthier members have access to better paying livelihood opportunities, or if unemployed, are unwilling to work for such low wages, indicating that they have access to other resources to maintain themselves. The classic public works programme is the Maharashtra Employment Guarantee Programme which originally provided guaranteed employment year round, within five kilometres of a 
beneficiary's residence. However, in 1988 the wage rate was doubled in line with a doubling of the minimum wage. While the programme still operates intensively, particularly in the slack agricultural season, evidence shows that overall days of employment have reduced, and employment places are rationed, eroding the insurance function (Datt and Ravallion 1994).

Wage rate setting is critical in the design of public works programmes and can be problematic in countries with minimum wage legislation, often enacted in support of human rights goals. In many poor countries the informal sector is dominant and the market wage in the sector is below any mandated minimum wage. If a public works programme is initiated to target the poorest with wages set at minimum wage levels, it will attract not only unemployed workers but also those from the informal sector. This is likely to result in employment rationing with the poorest being those potentially displaced. This creates a dilemma in the human rights field of economic, social and cultural rights. The progressive realization of these rights, including the right to food, where requires the maximization of resources going to the most food insecure people.

\section{Food subsidies}

These programmes, when universal, are generally the easiest to obtain political support for as they are, by default, available to all. In essence they increase household purchasing power by reducing the price of certain foods. The degree of subsidy received depends on the amount of the subsidized food purchased. So while the subsidy as a percentage of household food expenditure may be greater for the poor, the absolute value of the subsidy received maybe greater for richer households. In Tunisia in 1990, the poorest quintile received just 17 per cent of the subsidies on food compared to 20 per cent received by the rich. But in relative terms, the subsidies were progressive, representing 8.7 per cent of the total expenditures of the poor and just 3.5 per cent of the rich (Tuck and Lindert 1996). In a review of 85 social protection programmes, Coady, Grosh and Hoddinott find that seven of the ten worst performing programmes in terms of delivering benefits disproportionately to the poor were food subsidy programmes that were largely universal.

These subsidies can be targeted either by quotas or rationing using other targeting criteria or by subsidizing inferior foods; consumption falls as income rises. In Tunisia universal food subsidies were reformed, using self-targeting mechanisms that recognized different food habits between poor and wealthy people. Subsidies were removed from olive oil, the oil preferred by consumers, but were present on generic grain oil purchased in stores from a vat, as opposed to being prepackaged in individual bottles. This discouraged consumption by wealthier groups who preferred purchasing bottles of olive oil. Similarly, milk subsidies were restricted to reconstituted milk in smaller, less convenient packages as opposed to fresh milk in preferred packaging (Tuck and Lindert 1996). These programmes are consistent with the progressive realization of the right to food in that they prioritize resources to the most food insecure and do not use foods that are inferior from the perspective of food safety, only from the perspective of choice.

\section{Food stamps}

Food stamps/vouchers/coupons also increase the available purchasing power of a household but give recipients a greater degree of choice than direct food transfers. 
While households can reduce their own purchase of food items to increase available cash resources, evidence from the USA indicates that food consumption is increased by more than using an equivalent cash transfer (Fraker et al. 1995). A food stamp programme requires a well-developed retail food sector, and a secure and ready means of redemption for the retail sector to encourage them to accept the stamps. They also require a secure instrument and delivery mechanism to reduce the likelihood of a secondary 'currency' market in food stamps. Fraudulent duplication of food stamps can have unanticipated and significant impacts on government budgets. For these reasons food stamps tend not to have been widely used in the poorest developing countries, although there has been some success using them as an incentive system to utilize other social programmes.

As illustrated, the safety net instruments using food are numerous, able to support both a social assistance and insurance roles, and hence developmental role. Safety nets targeted to food security and the mitigation or prevention of undernutrition yield benefits throughout the lifecycle. Maternal malnutrition increases the likelihood of low birthweight babies that increase the likelihood of child undernutrition and the onset of chronic noncommunicable diseases in adulthood such as diabetes, hypertension, and cardiovascular diseases (Ruel 2001; Barker 1998). Undernourished children enrol in school later, repeat more grades, and have lower school achievements (Pollitt 1990; Behrman 1996). This lowered accumulation of human capital together with stunting (impaired height as a result of chronic undernutrition) lowers lifetime earnings (Alderman, Hoddinott and Kinsey 2003; Haddad and Bouis 1991; Strauss and Thomas 1998).

The relief-to-development framework adopted in the 1990s has not been effective: its sequential nature does not reflect the reality in the field nor a clear path from emergency programmes to development-based activities. The reality of many shock-prone, chronically food-insecure countries is that relief and development can and often do occur in the same spatial environment at the same time (CARE 2003; Haddad and Frankenberger 2003). Where humanitarian action is ad hoc, the development of a social protection system provides an opportunity to transform haphazard safety net programmes into a nationwide system to support communities, households and individuals in achieving secure livelihoods 4 (Devereux and Sabates-Wheeler 2004).

\section{Conclusions}

There is increasing recognition that safety nets need to be part of an overall social protection strategy. A social protection approach offers the opportunity for an integrated relief and development framework as opposed to the current linear sequencing. Safety nets protect the chronically food insecure, who may never be able support themselves, and as such fulfil a governments obligations to assure an acceptable standard of living for all its citizens. When incorporated in a well articulated social protection system they enable the poor to engage in livelihood strategies that offer the potential for pathways

4 Following De Haan (2000: 2), 'adopting social protection as an organizing framework 'helps to re-focus social protection policies, moving beyond a residualist welfare agenda dealing with the negative social consequences of economic changes and transitions, towards holistic approaches that inform the wide range of policies that affect the wellbeing of the poor'. 
out of poverty, by providing risk mitigating opportunities. Safety nets delivered using food linked transfers have a critical role to play, and are used to achieve different goals to those delivered in cash. Promising experiences are emerging worldwide where predictable safety nets, both food and cash based, are explicitly designed to promote the graduation of households out of chronic food insecurity. Examples include the widely documented Mexican PROGRESA/Oportunidades, or the more recent Ethiopian Productive Safety Net Programme, Afghanistan's Livelihoods and Social Protection Public Investment Programme, Malawi's Joint Integrated Safety Net Programme, and Ecuador's social protection strategy implemented under the newly-established Frente Social. While the overall direction looks promising, most of these strategies are in the early stages and cannot yet be evaluated in terms of how many people graduate, and whether graduation is permanent or consists of several periods of reutilization of the safety net.

\section{References}

Abdulai, A., C. Barrett, and P. Hazell (2004). 'Food Aid for Market Development in Sub-Saharan Africa’. Development Strategy and Governance Discussion Paper No. 5. Washington, DC: IFPRI.

Alderman, H. (2002). 'Subsidies as Social Safety Nets: Effectiveness and Challenges'. WB Social Protection Discussion Paper No. 0224. Washington, DC: World Bank.

Alderman, H., and C. Paxson (1992). 'Do the Poor Insure? A Synthesis of the Literature on Risk and Consumption in Developing Countries'. WB Policy Research Working Paper No. 1008. Washington, DC: World Bank.

Alderman, H., J. Hoddinott, and B. Kinsey (2003). 'Long-Term Consequences of Early Childhood Malnutrition'. Food Consumption and Nutrition Discussion Paper No. 168. Washington, DC: IFPRI.

Alwang, J., P. Siegel, and S. Jorgensen (2001). 'Vulnerability: A View from Different Disciplines'. WB Social Protection Discussion Paper No. 0115. Washington, DC: World Bank.

Barrett, C. (2002). 'Food Security and Food Assistance Programs', in B. L. Gardner and G. C. Rausser (eds), Handbook of Agricultural Economics. Amsterdam: Elsevier Science, North-Holland.

Barrett, C., and D. Maxwell (2005). Food Aid After Fifty Years: Recasting Its Role. London: Routledge.

Behrman, J. (1993). 'The Economic Rationale for Investing in Nutrition in Developing Countries’. World Development, 21 (11): 1749-72.

Behrman, J. (1996). 'The Impact of Health and Nutrition on Education'. World Bank Research Observer, 1: 23-37.

Binswanger, H. (1980). Attitudes towards Risk: Experimental Measurement in Rural India'. American Journal of Agricultural Economics, 62 (3): 395-407.

Bird, K., K. Moore, D. Hulme, and A. Shepherd (2002). 'Chronic Poverty and Remote Rural Areas'. CPRC Working Paper No. 13. Manchester: Chronic Poverty Research Centre. 
CARE (2003). 'Managing Risk, Improving Livelihoods: Program Guidelines for Conditions of Chronic Vulnerability'. Nairobi: Eastern and Central Africa Management Unit.

Castaneda, T. (2000). 'The Design, Implementation and Impact of Food Stamps Programs in Developing Countries'. Nutrition Toolkit No. 6. Washington, DC: World Bank.

Coady, D., M. Grosh, and J. Hoddinott (2004). The Targeting of Transfers in Developing Countries: Review of Experience and Lessons. Washington, DC: World Bank and IFPRI.

Conway, T., and A. Norton (2002). 'Nets, Ropes and Ladders and Trampolines: The Place for Social Protection within Current Debates on Poverty Reduction'. Development Policy Review, 20 (5): 533-40.

CPRC (Chronic Poverty Research Centre) (2004). Chronic Poverty Report 2004-05. Manchester: CPRC.

Datt, G., and M. Ravallion (1994). 'Income Gains for the Poor from Public Works Employment: Evidence from Two Indian Villages’. WB Working Paper No. 100. Washington, DC: World Bank.

Davies, S. (1996). Adaptable Livelihoods. Coping with Food Insecurity in the Malian Sahel. Basingstoke: Macmillian.

de Haan, A. (2000). 'Introduction: The Role of Social Protection in Poverty Reduction', in T. Conway, A. de Haan and A. Norton (eds), Social Protection: New Directions of Donor Agencies. London: Social Development Department, ODI.

de Janvry, A., M. Fafchamps, and E. Sadoulet (1991). 'Peasant Household Behavior with Missing Markets: Some Paradoxes Explained’. Economic Journal, 101 (409): 1400-17.

del Ninno, C., and P. Dorosh (2002). 'In-Kind Transfers and Household Food Consumption: Implications for Targeted Food Programmes in Bangladesh'. Food Consumption and Nutrition Discussion Paper No. 134. Washington, DC: IFPRI.

Dercon, S. (ed.) (2004). Insurance Against Poverty. Oxford: Oxford University Press for UNU-WIDER.

Devereux, S. (2002a). 'Can Social Safety Nets Reduce Chronic Poverty?’. Development Policy Review, 20 (5): 657-75.

Devereux, S. (2002b). 'Social Protection for the Poor: Lessons from Recent International Experience’. IDS Working Paper No. 142. Brighton: IDS.

Devereux, S. (2003). 'Policy Options for Increasing the Contribution of Social Protection to Food Security'. Theme paper prepared for the Forum for Food Security in Southern Africa. Sussex: Institute of Development Studies.

Devereux, S., and R. Sabates-Wheeler (2004). ‘Transformative Social Protection'. IDS Working Paper No. 232. Brighton: IDS.

Ellis, F. (2003). 'Human Vulnerability and Food Insecurity: Policy Implications'. Theme paper prepared for the Forum for Food Security in Southern Africa London: ODI. Available at: www.odi.org.uk/Food-Security-Forum/Index.html 
Fafchamps, M., and J. Pender (1997). 'Precautionary Saving, Credit Constraints, and Irreversible Investment: Theory and Evidence from Semi-Arid India'. Journal of Business and Economic Statistics, 15 (2): 180-94.

FAO (Food and Agriculture Organization) (1996). World Food Summit Plan of Action. Rome: FAO/WFP. Available at: www.fao.org/docrep/X2051e/X2051e00.htm \#P280_30375

Fogel, R. W. (2004). The Escape from Hunger and Premature Death, 1700-2100. Cambridge: Cambridge University Press.

Fraker, T. M., A. P. Martini, J. C. Ohls, and M. Ponza (1995). 'The Effect of Cashing Out Food Stamps on Household Food Use and the Cost of Issuing Benefits'. Journal of Policy Analysis and Management, 14 (3): 372-92.

Frankenberger, T. (2003). 'Chronic and Transitory Food Insecurity', in World Food Programme (ed.), Key Issues in Emergency Needs Assessment, Vol. II. Rome: WFP, 21-36.

Grosh, M. (1994). Administering Targeted Social Programs in Latin America. From Platitudes to Practice. Washington, DC: World Bank.

GTZ (Deutsche Gesellschaft für Technische Zusammenarbeit) (2004). 'Social Health Insurance: Systems of Solidarity. Experiences from German Development Cooperation'. Bonn: GTZ.

Haddad, L. J. and H. E. Bouis (1991). 'The Impact of Nutritional Status on Agricultural Productivity: Wage Evidence from the Philippines. Oxford Bulletin of Economics and Statistics, 53 (1): 45-68.

Haddad, L., and M. Zeller (1996). 'How can Safety Nets do More with Less? General Issues with some Evidence from Southern Africa'. Food Consumption and Nutrition Discussion Paper No. 16. Washington, DC: IFPRI.

Haddad, L., and T. Frankenbergr (2003). 'Integrating Relief and Development to Accelerate Reductions in Food Insecurity in Shock-Prone Areas'. Occasional Paper No. 2. Washington, DC: USAID/Office of Food for Peace.

Haddad, L., H. Alderman, and J. Hoddinott (eds) (1997). Intrahousehold Resource Allocation in Developing Countries. Models, Methods, and Policy. Baltimore: Johns Hopkins University Press.

Heitzmann, K., R. Canagarajah, and P. Siegel (2002). 'Guidelines for Assessing the Sources of Risk and Vulnerability'. WB Social Protection Discussion Paper No. 0218. Washington, DC: World Bank.

Higgins, P. A., and H. Alderman (1997). 'Labour and Women's Nutrition. The Impact of Work Effort on Nutritional Status in Ghana'. Journal of Human Resources, 32 (3): 577-95.

Hoddinott, J., and A. Quisumbing (2003). 'Data Sources for Microeconometric Risk and Vulnerability Assessments’. WB Social Protection Discussion Paper No. 0323. Washington, DC: World Bank.

Holzmann, R., and S. Jorgensen (2000). 'Social Risk Management: A New Conceptual Framework for Social Protection and Beyond'. WB Social Protection Discussion Paper No. 0006. Washington, DC: World Bank. 
ISDR (International Strategy for Disaster Reduction) (2002). Living with Risk. A Global Review of Disaster Reduction Initiatives. Geneva: ISDR.

Jalan, J., and M. Ravallion (2001) 'Behavioural Responses to Risk in Rural China'. Journal of Development Economics, 66 (1): 23-49.

Katz, E. (1992). 'Intrahousehold Resource Allocation in the Guatemalan Central Highlands: The Impact of Non-traditional Agricultural Exports'. Madison: University of Wisconsin. PhD dissertation.

Khogali, H., and P. Takhar (2001). 'Empowering Women through Cash Relief in Humanitarian Contexts’. Gender and Development, 9 (3): 40-9

Kurosaki, T., and M. Fafchamps (2002). 'Insurance Market Efficiency and Crop Choices in Pakistan'. Journal of Development Economics, 67 (2): 419-53.

Lautze, S., Y., Aklilu, A. Raven-Roberts, H. Young, G. Kebede, and J. Leaning (2003). 'Risk and Vulnerability in Ethiopia: Learning From the Past, Responding to the Present, Preparing for the Future'. Report for USAID. Medford: Tufts University.

Ligon, E., and L. Schechter (2002). 'Measuring Vulnerability'. Paper presented at the Conference on Risk and Vulnerability: Estimation and Policy Implications. Washington, DC.

Lokshin, M., and M. Ravallion (2000). 'Welfare Impacts of Russia’s 1998 Financial Crisis and the Response of the Public Safety Net'. Economics of Transition, 8 (2): 269-95.

Lokshin, M., and M. Ravallion (2001). 'Household Income in Two Transition Economies'. Washington, DC: World Bank. Mimeo.

Maxwell, D., C. Ahiadeke, C. Levin, M. Armar-Klemesu, S. Zakariah, and G. Lamptey (1999). 'Alternative Food-Security Indicators: Revisiting the Frequency and Severity of Coping Strategies’. Food Policy, 24 (4): 411-29.

Maxwell, S. (1996). 'Food Security. A Post-Modern Perspective'. Food Policy, 21 (2): 155-70.

Maxwell, S. (1998). 'Saucy With the Gods: Nutrition and Food Security Speak to Poverty’. Food Policy, 23 (3/4): 215-30.

Maxwell, S. (2001). 'The Evolution of Thinking About Food Insecurity'. in S. Maxwell and S. Devereux (eds), Food Security in Sub-Saharan Africa. Warwickshire: ITDG Publishing.

Maxwell, S., and R. Slater (2003). 'Food Policy Old and New'. Development Policy Review, 21 (5-6): 531-53.

Maxwell, S., and T. Frankenberger (1993). Household Food Security: Concepts, Indicators, Measurement. A Technical Review. New York: UNICEF and Rome: IFAD.

McKay, A. and D. Lawson (2002). 'Chronic Poverty: A Review of Current Quantitative Evidence’. CPRC Working Paper No. 15. Manchester: Chronic Poverty Research Centre.

McKay, A., and D. Lawson (2003). 'Assessing the Extent and Nature of Chronic Poverty in Low Income Countries: Issues and Evidence'. World Development, 31 (3): 425-39. 
Moore, K. (2001). 'Frameworks for Understanding the Intergenerational Transmission of Poverty and Wellbeing in Developing Countries'. CPRC Working Paper No. 8. Manchester: Chronic Poverty Research Centre.

Morduch, J. (1995). 'Income Smoothing and Consumption Smoothing'. Journal of Economic Perspectives, 9 (3): 103-14.

Morley, S., and D. Coady (2003). From Social Assistance to Social Development: Targeted Education Subsidies in Developing Countries. Washington, DC: Center for Global Development and IFPRI.

Owens, T., and J. Hoddinott (1999). 'Investing in Development or Investing in Relief: Quantifying the Poverty Tradeoffs Using Zimbabwe Household Panel Data'. CSAE Working Paper. Oxford: Centre for the Study of African Economies, Oxford University.

Pollitt, E. (1990). Malnutrition and Infection in the Classroom. Paris: UNESCO.

Quisumbing, A., R. Lynn, H. Brown, L. S. Feldstein, I. Haddad, and C. Peña (1995). 'Women: the Key to Food Security'. Policy Report. Washington, DC: IFPRI.

Ravallion, M. (2003). 'Targeted Transfers in Poor Countries: Revisiting the Trade-Offs and Policy Options’. WB Social Protection Discussion Paper No. 0314. Washington, DC: World Bank.

Reutlinger, S., and J. van Holst Pellekaan (1986). 'Poverty and Hunger. Issues and Options for Food Security in Developing Countries’. WB Policy Study No. 9275. Washington, DC: World Bank.

Rogers, B., and J. Coates (2002). 'Food-Based Safety Nets and Related Programs'. Food Policy and Applied Nutrition Discussion Paper No. 12. Medford: Tufts University.

Ruel, M. (2001). 'Can Food Based Strategies Help Reduce Vitamin A and Iron Deficiencies? A Review of Recent Evidence'. Food Policy Review No. 5. Washington, DC: IFPRI.

Sen, A. (1981). Poverty and Famines: An Essay on Entitlements and Deprivation. Oxford: Oxford University Press.

Shepherd, A. (2004). 'General Review of Current Social Protection Policies and Programmes’. Paper prepared for DFID. London: DFID. Mimeo.

Siegel, P., and J. Alwang (1999). 'An Asset-Based Approach to Social Risk Management: A Conceptual Framework’. WB Social Protection Discussion Paper No. 9926. Washington, DC: World Bank.

Smith, W., and K. Subbarao (2003). 'What Role for Safety Net Transfers in Very Low Income Countries?'. WB Social Protection Discussion Paper No. 0301. Washington, DC: World Bank.

Strauss, J., and D. Thomas (1998). 'Health, Nutrition, and Economic Development'. Journal of Economic Literature, 36 (2): 766-817.

Subbarao, K. (2003). 'Systemic Shocks and Social Protection: Role and Effectiveness of Public Works Programs’. WB Social Protection Discussion Paper No. 0302. Washington, DC: World Bank. 
Subbarao, K., A. Bonnerjee, J. Braithwaite, S. Carvalho, K. Ezemenari, C. Graham, and A. Thompson (1997). Safety Net Programs and Poverty Reduction. Lessons from Cross-Country Experience. Washington, DC: World Bank.

Tabor, S. (2002). 'Assisting the Poor with Cash: Design and Implementation of Social Transfers Programs'. WB Social Protection Discussion Paper No. 0223. Washington, DC: World Bank.

Tesliuc, E., and K. Lindert (2002). 'Vulnerability: A Quantitative and Qualitative Assessment'. Paper presented at the Conference on Risk and Vulnerability: Estimation and Policy Implications. Washington, DC.

Thomas, D. (1990). 'Intrahousehold Resource Allocation: An Inferential Approach'. Journal of Human Resources, 25 (4): 635-64.

Tuck, L., and K. Lindert (1996). 'From Universal Subsidies to a Self Targeted Program. A Case Study in Tunisian Reform'. WB Discussion Paper No. 351. Washington, DC: World Bank.

USAID (2003). 'Concept Paper for its Strategic Plan 2004-2008'. Document DCHA/FFP. Washington, DC: USAID.

Van Ginneken, W. (2003). 'Extending Social Security: Policies for Developing Countries’. International Labor Review, 142 (3): 277-94.

Von Braun, J., T. Teklu, and P. Webb (1999). Famine in Africa. Causes Responses, and Prevention. Baltimore, MD: John Hopkins University Press.

Walker, T., and J. Ryan (1990). Village and Household Economies in India's Semi-Arid Tropics. Baltimore, MD: Johns Hopkins University Press.

Watts, H., and G. Bohle (1993). Hunger, Famine and Space of Vulnerability. Dordrecht: Kluwer Academic

Webb, P. (2003). 'Food as Aid. Trends, Needs and Challenges in the 21st Century'. WFP Occasional Paper No. 14. Rome: World Food Programme.

Webb, P., and A. Harinarayan (1999). 'A Measure of Uncertainty: The Nature of Vulnerability and its Relationship to Malnutrition'. Disasters, 23 (4): 292-305.

Webb, P., and B. Rogers (2003). 'Addressing the “In” in Food Insecurity'. Occasional Paper No. 1. Washington, DC; USAID/Office of Food for Peace.

Webb, P., and J. Von Braun (1994). Famine and Food Security in Ethiopia: Lessons for Africa. London: John Wiley.

WFP (World Food Programme) (2002). 'Vulnerability Analysis and Mapping (VAM) Standard Analytical Framework. Guidelines for Core Activities’. Rome: WFP.

WFP (World Food Programme) (2004). 'Vulnerability, Social Protection and Food-based Safety Nets. Theory, Evidence and Policy Underpinnings’. Rome: PDP Division, WFP. Mimeo.

World Bank (2001). 'Social Protection Sector Strategy Paper: From Safety Net to Springboard'. Washington, DC: World Bank.

World Bank (2003). 'The Contribution of Social Protection to the Millennium Development Goals’. Washington, DC: World Bank. 